\title{
The Effect of Eco-efficiency and Size on Company Value Listed on the Indonesia Stock Exchange
}

\author{
Msy. Mikial ${ }^{1}$, Taufiq Marwa ${ }^{2}$, Luk Luk Fuada ${ }^{2}$, Inten Meutia ${ }^{2}$ \\ ${ }^{1}$ Faculty of Economics, Tridinanti University, Palembang, Indonesia \\ ${ }^{2}$ Faculty of Economics, Universitas Sriwijaya, Palembang, Indonesia \\ Correspondence: Msy. Mikial, Faculty of Economics, Tridinanti University, Palembang, Indonesia
}

Received: January 28, 2020

Accepted: March 5, $2020 \quad$ Online Published: March 8, 2020

doi:10.11114/bms.v6i1.4703

URL: https://doi.org/10.11114/bms.v6i1.4703

\begin{abstract}
This study aims to empirically examine the effect of eco-efficiency and company size on the value of companies listed on the Indonesia Stock Exchange. The data used are secondary data obtained from annual reports and sustainability reports of companies listed on the Indonesia Stock Exchange from 2013 to 2016. The number of observations in this study is 80 . The instrument used to analyze is Partial Least Square. The novelty in this study is that eco-efficiency is calculated by comparing the amount of net sales to energy consumption, and to measure a company size with a proxy for the number of sales. The results of this study indicate that eco-efficiency has an influence on company value. The direction of influence is negative, meaning that the better the eco-efficiency, the lower the value of the company. Company size does not affect the value of the company, in the sense that the sale value does not cause the value of the company to experience better changes, because the value of the company is more influenced by the assets owned by the company. The limitation of this study is that the amount of energy sources used is difficult to obtain, so the study population is limited to companies listed on the IDX that have a Sustainability Reporting and are included in the Sustainability Disclosure Database from the Global Reporting Initiative (GRI), which is not large. In the future it is expected that companies responsible for the environment implement environmental management accounting with eco-efficiency assessment indicators so as to reduce costs and environmental impacts by making more efficient use of resources so as to increase company value.
\end{abstract}

Keywords: eco-efficiency, company area and company value

\section{Introduction}

In recent years, the concept of sustainability has become a major issue in the development of the company. This concept arises from the demands and expectations of the community regarding the company's role in society. Sustainability Reporting is a trend and the need for companies to inform about their economic, social and environmental performance as well as all company stakeholders (Chariri \& Nugroho, 2009). Through this Sustainability Reporting, the company can maintain reputation, build stakeholder trust, show accountability and improve firm value. In Indonesia, a Sustainability Reporting is not a company obligation, so not many companies have published it, even though it has been listed on the Indonesia Stock Exchange.

The main goal of companies that have gone public is to increase the prosperity of their owners or shareholders through increasing the value of the company. The value of the company is very important because with high company value will be followed by high shareholder wealth, and what determines shareholder wealth is the share price. The higher the stock price the higher the company's value. The value of a company is determined by the level of profitability and growth rate of the company (Salvatore, 2005; Bringham and Houston, 2010). Company value is the market value of the debt securities and corporate equity in circulation.

There are several ratios to measure a company's market value, such as price-earnings ratio (PER), market-to-book ratio, market-to-sales ratio, Tobin's Q, and price / cash flow ratio. Each ratio has different characteristics, and provides information for management and investors about different matters (Sukamulja, 2004).

Environmental management accounting is an area of accounting that serves to provide two types of information for internal decision making, physical information about the use of energy, water and material flows (including waste) and 
monetary information about costs, income, and savings relating to the environment (UNDSD, 2001). Environmental management accounting incorporates physical and monetary information, making it possible for new types of analysis to be based on eco-efficiency indicators (the ratio between the environment and financial variables). The concept of eco-efficiency is a midpoint between the economy and the environment (Osazuwa \& Che-Ahmad, 2016).

Eco-efficiency is a tool for conducting industry sustainability analyzes, which shows economic relationships and environmental impacts and is used to monitor and evaluate the efficient use of resources and reduce the environmental impact of company operations. Efficient resources will improve the company's financial performance and will certainly also increase the value of the company. Expectations that develop in the community make the company take the initiative in business processes to adjust to the concept of eco-efficiency (Al-Najjar \& Anfimiadou, 2012).

There has not been much research on environmental management accounting with eco-efficiency proxies associated with firm value. From several studies, the results state that the application of environmental management accounting with eco-efficiency has a positive influence / relationship with firm value (Al-Najjar \& Anfimiadou, 2012); (Osazuwa \& Che-Ahmad, 2016) and (Guenster, Bauer, Derwall, \& Koedijk, 2011). Likewise Cho \& Patten, (2007) and Hyo Hook (2017) found a negative relationship between the level of disclosure of environmental conservation costs and eco-efficiency performance.

Companies that are able to increase profits will have the opportunity to expand. Expansion is an active action to expand and enlarge the company. Companies that have a larger size have an influence on increasing the value of the company (Hansen and Juniarti, 2014). The research results of Gill and Obradovich (2012) which states that company size has a positive effect on company value. This means that increasing company size will make it easier for companies to increase sales, thereby increasing company value. In contrast to research conducted by Naceur and Goaied (2002), the results of the study stated that company size has a negative effect on firm value.

The purpose of this study is to analyze and empirically test the effect of environmental management accounting with a proxy for eco-efficiency and company size on the value of companies listed on the Indonesia Stock Exchange and publish a Sustainability Reporting. The research was developed by way of explanation and justification of the data collected and continued with the results and implications.

\section{Literature Review}

\subsection{Theory of the Firms}

Coase (2012) states that to create efficiency within the company can be done through the delegation of authority through contracts that exist in a company, if the mechanism of production and exchange of goods is entirely based on market mechanisms. With the creation of efficiency, the company is expected to be able to create prosperity for its owners. The opinion of Coase (2012) is based on his view of "the nature of the firm" which eventually gave birth to the "theory of the firm".

It is generally agreed that company theory must address fundamental questions about what a company is and its role in society (Becerra, 2009). Company theory shows how companies can create value for customers and, at the same time, capture economic benefits for their owners through business, corporate, international and social strategies.

Theory of the Firm underlies the theory of the value of the firm. The main purpose of the company according to the theory of the firm is to maximize the company's wealth or company value (value of the firm) (Salvatore, 2005). Maximizing the value of the company is very important for a company, because maximizing the value of the company also maximizes the prosperity of shareholders which is the company's main goal. Wealth of shareholders and companies is represented by the market price of shares which is a reflection of investment decisions, financing (financing), and asset management.

\subsection{Company Value}

The company's main goal is to increase the value of the company. Company value is the investor's perception of the company's success in managing resources. For companies that issue shares in the capital market, the price of shares traded on the stock exchange is an indicator of company value. According to Fama \& French (2012) the value of the company will be reflected in its share price. Rising stock prices will certainly increase the value of the company. Keown (2004) states that the value of a company is the market value of the debt securities and corporate equity in circulation.

Black, Jang, \& Kim, (2006) mention three measures of company performance that can be used to see the value of the company, which are tobin Q, market to book ratio and market to sales ratio. Brealey and Myers (2000) in Sukamulja (2004) stated that companies with high Q values usually have a very strong corporate brand image while companies that have low $Q$ values generally are in very competitive industries or industries that are starting to shrink. The value of the company in this study was measured by tobin's Q Ratio. Tobin'q value is produced from the sum of the market value of 
all outstanding stocks and the market value of debt compared to the value of all capital placed in production assets (replacement value of all production capacity). According to Smithers and Wright (2002) the value of a company proxied by Tobin's $\mathrm{Q}$ is calculated by the following formula:

Note:

$$
\begin{aligned}
& \mathrm{Q}=\underline{\mathrm{EMV}+\mathrm{D}} \\
& \mathrm{EBV}+\mathrm{D}
\end{aligned}
$$

$$
\begin{aligned}
& \mathrm{Q}=\text { company value } \\
& \text { EMV = market value of equity } \\
& \mathrm{EBV}=\text { book value of total equity } \\
& \mathrm{D}=\text { book value of total debt }
\end{aligned}
$$

If the Q-ratio is above one, this shows that investment in assets produces a profit that gives a higher value than investment expenditure, this will stimulate new investment. If the Q-ratio is below one, investing in assets is not attractive. So the Q-ratio is a more precise measure of how effectively management utilizes economic resources in its power.

\subsection{Eco-efficiency}

Eco-efficiency is achieved by the delivery of competitively-priced goods and services that satisfy human needs and bring quality of life, while progressively reducing ecological impacts and resource intensity throughout the life-cycle to a level at least in line with the earths estimated carrying capacity "WBSCD (2000). The essence of eco-efficiency is to produce goods and services at competitive prices and provide added value to consumers without sacrificing or damaging the environment.

Eco-efficiency is a tool for the analysis of industrial sustainability, which shows economic relations and environmental impacts (Charmondusit, Phatarachaisakul, \& Prasertpong, 2014). Eco-efficiency explains the relationship between environmental performance and financial performance (Birkin \& Woodward, 1997). Eco-efficiency unites two economic and ecological dimensions to connect the value of products or services with environmental influences (United Nations Economic and Social Commission for Asia and the Pacific, 2009). Eco-efficiency can be represented by the following ratio:

$$
\begin{gathered}
\text { Eco-efficiency }=\text { Nilai produk atau layanan } \\
\text { Pengaruh lingkungan }
\end{gathered}
$$

A large ratio indicates a good eco-efficiency, while a small value indicates a bad eco-efficiency. The United Nations Economic and Social Commission for Asia and the Pacific, (2009) states so far, WBCSD has identified the following core indicators to be tested in trial applications:

Product / service value

- Number of goods / services produced or provided to customers

- Net sales

Effect of product / service creation environment

- Energy consumption

- Consumption of ingredients

- Water consumption

- Greenhouse Gas (GHG) Emissions to the Air

- Ozone Depleting Substance (ODS) Emissions to the Air.

\subsection{Company Size}

Company size is one of the variables considered in determining firm value. The size of the company is a reflection of the total assets owned by the company. The greater the size of the company, it means that the assets owned by the company are also getting bigger and the funds needed by the company to maintain its operational activities are increasing. The greater the size of the company will affect management decisions in deciding what funding will be used by the company so that funding decisions can optimize the value of the company. 
The size of the company according to Brigham \& Houston (2010:4) is a measure of the size of a company that is shown or valued by total assets, total sales, total profits, tax expenses and others. According to Riyanto (2011: 299), a large company in which its shares are very wide spread, each share capital expansion will only have a small effect on the possibility of loss or displacement of control from the dominant party over the company concerned. Conversely, a small company in which its shares are only spread in a small environment, an increase in the number of shares will have a large influence on the possibility of losing control of the dominant party over the company concerned.

\section{Development of Theory}

This research is based on the theory of the firm proposed by Coase (2012) which argues that a company is a business entity that aims to allocate production activities efficiently. With the creation of efficiency, it is expected that companies will be able to create prosperity for their owners. Firm theory shows how companies can create value for customers and, at the same time, capture economic benefits for their owners. The value of the company is the perception of capital owners of the level of success of many companies that relate it to the stock price. The higher the stock price, the higher the company's value.

\section{Hypothesis:}

H1: Eco-efficiency and company size jointly affect the value of companies listed on the Indonesia Stock Exchange.

H2: Eco-efficiency affects the value of companies listed on the Indonesia Stock Exchange.

H3: Company size influences the value of companies listed on the Indonesia Stock Exchange.

\section{Methodology}

\subsection{Data Sources and Data Collection Techniques}

The data collection method used in this study is documentation. Data sources are secondary data from electronic publications that can be accessed via the internet. Data obtained from various sources include data from ongoing reports and annual reports of companies on the Indonesia Stock Exchange and in the Sustainability Disclosure Database from the Global Reporting Initiative (GRI), from literature, journals and other sources related to problems in research.

\subsection{Population}

The population in this study are all companies listed on the Indonesia Stock Exchange in 2013-2016 which have the following criteria:

(1) Publish a complete Annual Report and Suitainability Report

(2) Having data regarding the disclosure of environmental information

(3) Have data regarding environmental costs

(4) Included in the Sustainability Disclosure Database of the Global Reporting Initiative (GRI)

Based on the determined criteria, only 20 companies were listed on the Indonesia Stock Exchange, published the Annual Report and Sustainability Report and included in the Sustainability Disclosure Database of the Global Reporting Initiative (GRI) during the 2013-2016 (4 years) period, so the number of observations was 80 .

Table 1. List of Companies Registered on the IDX in 2017

\begin{tabular}{|c|c|c|}
\hline $\mathrm{No}$ & Code & Company Name \\
\hline 1 & ANTM & Aneka Tambang (Persero) Tbk \\
\hline 2 & ASII & Astra International Tbk \\
\hline 3 & ELSA & Elnusa Tbk \\
\hline 4 & INCO & Vale Indonesia Tbk \\
\hline 5 & INDR & Indo Rama Synthetic Tbk \\
\hline 6 & INTP & Indocement Tunggal Prakasa Tbk \\
\hline 7 & ITMG & Indo Tambangraya Megah Tbk \\
\hline 8 & PTBA & Tambang Batubara Bukit Asam (Persero) Tbk \\
\hline 9 & PTRO & Petrosea Tbk \\
\hline 10 & SMCB & Holcim Indonesia Tbk \\
\hline 11 & SMGR & Semen Indonesia (persero) Tbk \\
\hline 12 & TINS & Timah (Persero) Tbk \\
\hline 13 & WTON & Wijaya Karya Beton Tbk \\
\hline 14 & PGAS & Perusahaan Gas Negara (Persero) Tbk \\
\hline 15 & UNTR & United Tractors Tbk \\
\hline 16 & BBNI & Bank Negara Indonesia Tbk \\
\hline 17 & BMRI & Bank Mandiri (persero) Tbk \\
\hline 18 & GIAA & Garuda Indonesia (persero) Tbk \\
\hline 19 & BNII & PT Bank Mybank Indonesia Tbk \\
\hline 20 & BBRI & Bank Rakyat Indonesi (persero) Tbk \\
\hline
\end{tabular}


Sumber: www.idx.co.id

\subsection{Operational Definition and Variable Measurement}

The variables in this study consisted of:

\section{Eco-Efficiency $\left(\mathrm{X}_{1}\right)$}

A business management that combines economic efficiency with environmental efficiency by comparing the value of products or services (economic value) with environmental influences. The formula is the ratio of the value of the product or service in the form of total net sales to energy consumption.

\section{Company Size $\left(\mathrm{X}_{2}\right)$}

A description of the size of a company that is shown in total assets, total sales, average sales and total assets

\section{Company Value (Y)}

The market value of the debt securities and corporate equity in circulation. The value of the company is the perception of capital owners of the level of success of many companies that relate it to the stock price. To measure the company's value proxied by using Tobin's Q. This ratio is measured from the market value of equity plus the book value of total liabilities then divided by the book value of equity plus the book value of total liabilities.

\subsection{Technique of Analysis}

The research model submitted to be tested is as follows:

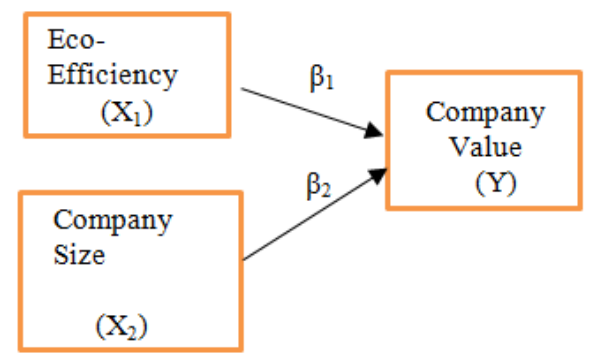

\section{Equation:}

$\mathrm{Y}=\beta_{1} \mathrm{X}_{1}+\beta_{2} \mathrm{X}_{2}+\varepsilon$

The analytical tool uses Smart PLS software. Partial Least Square (PLS) software is an analytical method that is soft modeling because it does not assume the data must be with a certain measurement scale, which means the number is small (under 100 samples).

\section{Result}

\subsection{Path Coefficient}

The efficiency of exogenous variable paths to endogenous variables can be seen in the Table 2 below:

Table 1. Path Coefficient

\begin{tabular}{|c|c|c|c|c|c|}
\hline & $\begin{array}{c}\text { Original Sample } \\
\text { (O) }\end{array}$ & $\begin{array}{c}\text { Sample Mean } \\
\text { (M) }\end{array}$ & $\begin{array}{l}\text { Standard } \\
\text { Error } \\
\text { (STERR) }\end{array}$ & $\begin{array}{c}\text { t-Statistics } \\
\text { (|O/STERR|) }\end{array}$ & P Values \\
\hline $\begin{array}{l}\text { Eco-Effisiency (X1) -> } \\
\text { Company value (Y) }\end{array}$ & $-0,141$ & $-0,138$ & 0,059 & 2,375 & 0,018 \\
\hline $\begin{array}{l}\text { Size (X2) -> Company } \\
\text { value }(\mathbf{Y})\end{array}$ & $-0,004$ & $-0,006$ & 0,140 & 0,031 & 0,975 \\
\hline
\end{tabular}

4.2 The Effects of Eco-Efficiency Company Value

Based on the estimation results shown in Table 2, it can be seen that Eco-efficiency (X1) which is an environmental management accounting proxy affects the value of the company $(\mathrm{Y})$. This condition is marked by a statistical $t$ value of 2.375 and a $\mathrm{p}$ value of $0.018<0.05$. The direction of influence is negative, meaning that the better the eco-efficiency as measured by the ratio of total net sales to energy consumption, the value of the company will decrease. 
The results of this study contradict the previous research conducted by Al-Najjar \& Anfimiadou (2012) and Osazuwa \& Che-Ahmad (2016) which states that the application of environmental management accounting and environmental policy through eco-efficiency has a positive relationship with firm value.

The results of this study tend to support research from Waddock \& Graves (1997) which states that reducing internal costs such as environmental costs due to efficiency will only lead to higher external costs such as payment of bondholders because the company may be considered to have a higher risk that can reduce the value company. Corrective actions on the environment require huge costs because investments in technology needed to engineer environmentally friendly technologies and products to reduce the terrible impact on the immediate environment, and to comply with eco-efficient requirements require large expenditures, in the sense of requiring high and risky investments so that investors will guard against its investment and that can reduce the value of the company.

In addition, the effect of eco-efficiency on company value which results are negative, means that the company has not optimally applied environmental management accounting in carrying out its business activities related to the environment. This can be seen from the fact that not many public companies have published sustainable reports which are products of environmental management accounting.

For companies that have adopted eco-efficiency as a way of operating, and thus are able to maintain costs and have increased their profits, are likely to experience higher value than companies that have failed to adopt the policy (Sinkin, Wright, \& Burnett, 2008).

\subsection{The Effects of Company Size on Company Value}

Based on the estimation results shown in Table 2, it can be seen that company size (X2) affects the value of the company (Y). This condition is marked by a statistical $t$ value of 2.375 and a p value of $0.018<0.05$. Company size (X2) does not affect Company Value (Y1). This condition is marked by a statistical $t$ value of 0.031 and a $\mathrm{p}$ value of 0.975 is not significant at the $\alpha$ level of $5 \%$. The results of this study were not in line with some of the results of previous studies which stated that the size of the company affects the value of the company, such as the results of the research of Gill and Obradovich (2012), Niresh and Velnampy (2014), and Martikarini, 2012. The results of their research can explain that Size Large companies will increase company value. The results of this study are in line with research conducted by Naceur and Goaied (2002) which states that no effect was found between company size and company value. The size of the company in this case is measured by the number of sales. The number of sales is high but if the results are absorbed a lot to meet the requirements of eco-efficiency which requires a large cost at the the beginning it will cause the company's profits to decline and certainly will not increase the value of the company

\section{Conclusions, Limitations and Recommendations}

\subsection{Conclusions}

Based on the formulation of the problem, the formulation of the hypothesis and the results of the study, the following conclusions can be drawn: Eco-efficiency which is a proxy for environmental management accounting significantly influences company value. The direction of the influence of eco-efficiency on company value is negative, which indicates that if eco-efficiency is high it will reduce the value of the company. This is due to the cost of doing high eco-efficiency so that profits decline and will also reduce the value of the company. Company size has no effect on company value. The size of the company in this case is measured by the number of sales. The number of sales is high but the results are absorbed a lot to meet the requirements of eco-efficiency which requires large costs in the beginning will cause the company's profit does not increase and certainly will not increase the value of the company

\subsection{Limitations}

This study has the following limitations:. Data on the amount of energy sources used by companies is difficult to obtain so the study population is limited to companies listed on the IDX that have a Sustainability Report and are included in the Sustainability Disclosure Database of the Global Reporting Initiative (GRI). In addition, this study only focuses on two variables that affect company value, namely eco-efficiency and company size.

\subsection{Recommendations}

Based on the conclusions, the company responsible for the environment is expected to implement environmental management accounting with eco-efficiency assessment indicators so that it can reduce costs and environmental impacts by making more efficient use of resources so as to increase the value of the company.

\section{References}

Al-Najjar, B., \& Anfimiadou, A. (2012). Environmental policies and firm value. Business Strategy and the Environment. https://doi.org/10.1002/bse.713 
Artene, A. E., Domil, A. E., \& Sabau, C. (2012). Environmental management accounting and the opportunity cost of environment management systems. Anale. Seria Stiinte Economice. Timisoara, 18, 718.

Ata, H. A. (2016). İmalat Şirketlerinde Çalışma Sermayesi Etkinli ğ inin Firma De ğerine Etkisi Nasıldır? How Working Capital Management Effect Firm Value In Manufacturing Companies, (35), 25-33

Azizah, N., Moch, D., Endang, A. R., Maria, G. W. (2013). Analisis Penerapan Environtmental Management Accounting (EMA) sebagai bentuk Eco-Effisiency dalam meningkatkan Keunggulan Kompetitif Perusahaan (Studi Pada PT. Perkebunan Nusantara X Unit Usaha Pabrik Gula Ngadiredjo Kabupaten Kediri Periode Tahun 2009-2011). Jurnal Administrasi Bisnis (JAB), 6(2).

Becerra, M. (2009). Theory of the firm for strategic management: economic value analysis. Cambridge University Press. https://doi.org/10.1017/CBO9780511626524

Brigham, E. F., \& Houston, J. F. (2010). Dasar-dasar Manajemen Keuangan, Edisi ke-11. Jakarta: Salemba Empat.

Chariri, A., \& Nugroho, F. A. (2009). Retorika Dalam Pelaporan Corporate Social Responsibility: Analisis Semiotik Atas Sustainability Reporting. Simposiun Nasional Akuntansi, XII(5), 0-23.

Charmondusit, K., Phatarachaisakul, S., \& Prasertpong, P. (2014). The quantitative eco-efficiency measurement for small and medium enterprise: A case study of wooden toy industry. Clean Technologies and Environmental Policy, 16(5), 935-945. https://doi.org/10.1007/s10098-013-0693-4

Coase, R. (2012). The nature of the firm. The Economic Nature of the Firm: A Reader, Third Edition, 4(16), 79-95. https://doi.org/10.1017/CBO9780511817410.009

Crisóstomo, V. L., De Souza, F. F., \& De Vasconcellos, F. C. (2011). Corporate social responsibility, firm value and financial performance in Brazil. Social Responsibility Journal, 7(2), 295-309. https://doi.org/10.1108/17471111111141549

Draft, E. (2004). International Guidelines on Environmental Management Accounting (EMA).

Fama, E. F., \& French, K. R. (2012). Size, value, and momentum in international stock returns. Journal of Financial Economics. https://doi.org/10.1016/j.jfineco.2012.05.011

Feng, T., \& Wang, D. (2016). The Influence of Environmental Management Systems on Financial Performance: A Moderated-Mediation Analysis. Journal of Business Ethics, 135(2), $265-278$. https://doi.org/10.1007/s10551-014-2486-z

Figge, F., \& Hahn, T. (2013). Value drivers of corporate eco-efficiency: Management accounting information for the efficient use of environmental resources. Management Accounting Research, 24(4), 387-400. https://doi.org/10.1016/j.mar.2013.06.009

Gamayuni, R. R. (2015). The Effect Of Intangible Asset, Financial Performance and Financial Policies on The Firm Value. International Journal of Economics and Financial Issues, 4(01), 202-212.

Ghozali, I. (2014). Struktural Equation Modeling Metode Alternatif dengan Partial Least Squares (PLS) dilengkapi Software Smartpls 3.0. Xlstat 2014 Dan Warpls, 4.

Gill, A., \& Obradovich, J. D. (2012). The Impact of Corporate Governance and Financial Leverage on the Value of American Firms. International Research Journal of Finance and Economics, 91.

Guenster, N., Bauer, R., Derwall, J., \& Koedijk, K. (2011). The Economic Value of Corporate Eco-Efficiency. European Financial Management, 17(4), 679-704. https://doi.org/10.1111/j.1468-036X.2009.00532.X

Hansen, D. R., \& Mowen, M. M. (2007). Managerial Accounting. https://doi.org/10.1111/j.1751-908X.2002.tb00883.x

International Federation of Accountants. (2005). International Guidelines on Environmental Management Accounting ( EMA ), (November 2004), 1-65.

Jensen, M. C., \& Meckling, W. H. (1976). Theory of the firm: managerial behaviour, agency costs and ownership structure. Journal of Financial Economics, 19, 127-68. https://doi.org/10.1016/0304-405X(76)90026-X

Keown, K., Petty, M., \& Scott. (2004). Manajemen Keuangan 1 dan 2. Edisi 9 (terjemahan). Jakarta. Indeks.

Markus, L. (2000). Eco-efficiency creating more value with less impact. World Business Council for Sustainable Development.

Martikarini, N. (2012). The Effect of Profitability, Debt Policy, and Dividends on the Value of Manufacturing Companies Listed on the Indonesia Stock Exchange in the 2009-2011 Period. Journal of the Faculty of Economics, Gunadarma University. 
Mulyadi. (2007). Activity Based Cost System. Ed. 6. Yogyakarta: UPP STIM YKPN.

Munteanu, A. R. (2013). Environmental Management Accounting (Ema) Implementation: Motivation and Expected Results From a Business Perspective. Romanian Journal of Economics, 2(46), 164-173. Retrieved from http://www.revecon.ro/articles/2013-2/2013-2-12.pdf

Niresh, A., \& Thirunavukkarasu, V. (2014). Firm size and profitability: A study of listed manufacturing firms in Sri Lanka. International Journal of Business and Management, 9(4). https://doi.org/10.5539/ijbm.v9n4p57

Osazuwa, N. P., \& Che-Ahmad, A. (2016). The moderating effect of profitability and leverage on the relationship between eco-efficiency and firm value in publicly traded Malaysian firms. Social Responsibility Journal, 12(2), 295-306. https://doi.org/10.1108/SRJ-03-2015-0034

Salvatore, D. (2005). Ekonomi Manajerial dalam Perekonomian Global. Salemba Empat: Jakarta.

Sinkin, C., Wright, C. J., \& Burnett, R. D. (2008). Eco-efficiency and firm value. Journal of Accounting and Public Policy. https://doi.org/10.1016/j.jaccpubpol.2008.01.003

Smithers, A., \& Wright, S. (2002). Valuing Wall Street: protecting wealth in turbulent markets. McGraw-Hill Companies.

Sukamulja, S. (2004). Good Corporate Governance Di Sektor Keuangan: Dampak GCG Terhadap Kinerja Perusahaan ( Kasus di Bursa Efek Jakarta ). Benefit, Fakultas Ekonomi Universitas Atma Jaya Yogyakarta, 8(1), 1-25. Retrieved from http://journals.ums.ac.id/index.php/benefit/article/download/1193/761

Thant, M. M., \& Charmondusit, K. (2010). Eco-efficiency assessment of pulp and paper industry in Myanmar. Clean Technologies and Environmental Policy, 12(4), 427-439. https://doi.org/10.1007/s10098-009-0232-5

Tsui, C. S. K. (2014). A Literature Review on Environmental Management Accounting (EMA) Adoption. Web Journal of Chinese Management Review, 17(3), 1-19.

UNDSD. (2001). Environmental Management Accounting Procedures and Principles. https://doi.org/10.1007/0-306-48022-0_3

United Nations Economic and Social Commission for Asia and the Pacific. (2009). Eco-efficiency Indicators: Measuring Resource-use Efficiency and the Impact of Economic Activities on the Environment, The greening of economic series. United Nations publication. https://doi.org/10.1185/135525706x105028

Waddock, S. A., \& Graves, S. B. (1997). The corporate social performance-financial performance link. Strategic Management Journal. https://doi.org/10.1002/(SICI)1097-0266(199704)18:4<303::AID-SMJ869>3.0.CO;2-G

\section{Copyrights}

Copyright for this article is retained by the author(s), with first publication rights granted to the journal.

This is an open-access article distributed under the terms and conditions of the Creative Commons Attribution license which permits unrestricted use, distribution, and reproduction in any medium, provided the original work is properly cited. 